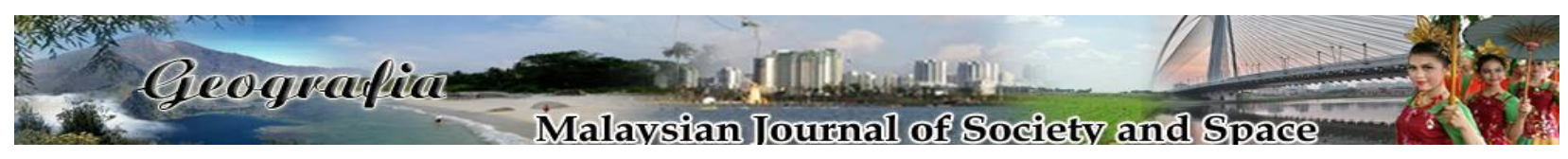

\title{
Spesifikasi ruang dalam kata kerja deiktik datang dan pergi
}

\author{
Maslida Yusof, Karim Harun \\ Pusat Kajian Bahasa, Kesusasteraan dan Kebudayaan Melayu, Fakulti Sains Sosial dan Kemanusiaan, \\ Universiti Kebangsaan Malaysia
}

Correspondence: Maslida Yusof (email: maslida@ukm.edu.my)

Received: 22 March 2021; Accepted: 07 May 2021; Published: 29 May 2021

\begin{abstract}
Abstrak
Makalah ini meneliti kata kerja deiktik datang dan pergi sebagai spesifikasi ruang dalam bahasa Melayu. Kata kerja deiktik yang juga dipanggil sebagai kata kerja gerak deiktik merujuk kepada mana-mana kata kerja yang menandakan arah bagi sesuatu entiti sedang bergerak seperti datang dan pergi. Justeru dalam usaha untuk memahami komponen deiktik dalam kata kerja gerak datang dan pergi, maka kajian ini mengambil 100 konkordans kata kerja datang dan 100 konkordans kata kerja pergi daripada Pangkalan Data Korpus Dewan Bahasa dan Pustaka. Dalam menganalisis kata kerja gerak deiktik datang dan pergi, kajian ini menggunakan Model Talmy yang berasaskan kepada konsep pusat deiktik. Pusat deiktik merupakan titik rujukan yang ekspresi deiktik bergantung kepadanya. Berdasarkan data daripada korpus bahasa Melayu, kata kerja pergi menunjukkan makna "BERGERAK KE ARAH" titik yang bukan merupakan lokasi penutur/peserta. Manakala makna leksikal kata kerja datang adalah "GERAK KE (ARAH)" titik yang merupakan lokasi penutur. Selain itu, analisis data korpus juga dapat menjelaskan bahawa kata kerja gerak datang berdasarkan orientasi perspektif-ketibaan sedangkan kata kerja gerak pergi berdasarkan orientasi perspektif-perlepasan. Kajian ini secara tidak langsung menunjukkan kelas kata kerja gerak bahasa Melayu sebagaimana bahasa-bahasa lain yang telah dikaji mengandungi secara asasnya Objek, pergerakannya melalui Laluan yang berhubungan dengan objek yang lain (Tanda Tempat).
\end{abstract}

Kata kunci: Kata kerja deiktik, kata kerja gerak, datang, pergi, pusat diektik, ruang

\section{Spatial specification in deictic verbs datang and pergi}

\begin{abstract}
This paper examines the deictic verb datang (come) and pergi (go) as spatial specifications in Malay language. A deictic verb which is also called a deictic motion verb refers to any verb that
\end{abstract}


indicates the direction for an entity is moving such as datang and pergi. Thus to understand the deictic component in the motion verbs of datang and pergi, this study utilizes 100 concordance of the verbs of datang and 100 concordance of the verbs of pergi from the Dewan Bahasa dan Pustaka Corpus Database. In analysing the deictic motion verbs datang and pergi, this study employs Talmy's model which based on the concept of the deictic centre. The deictic centre is the reference point to which the deictic expression is anchored to. Based on data from the corpus, the verb pergi show the meaning of "MOVING TOWARDS" to a point that is not the location of speakers/participants. While the lexical meaning of the verb datang is "MOVE TO (DIRECTION)" the point which is the location of the speaker. In addition, corpus data analysis can also explain that motion verbs datang is based on perspective-arrival orientation while motion verbs pergi is based on perspective-departure orientation. As other languages which have been studied, this study implies that the motion verbs in Malay contain basically Objects (The Figure), and its movement through a Path (the Path) which is associated with another object (the Ground).

Keywords: Deictic verbs, motion verbs, datang (come), pergi (go), deictic centre, spatial

\section{Pengenalan}

Dalam perbincangan tentang deiksis, kata kerja gerak deiktik datang dan pergi telah menjadi sebahagian daripada perbincangan yang berterusan dalam bahasa. Dalam makalah ini, akan difokuskan pada kata kerja datang dan pergi yang bertujuan untuk memberikan penerangan dan penjelasan bagi komponen makna deiktik kata kerja tersebut.

Deiksis adalah bidang yang penting dalam linguistik moden terutamanya dalam bidang semantik dan pragmatik. Deiksis merupakan fenomena yang mana makna bagi perkataan dan frasa tertentu dalam ujaran memerlukan maklumat kontekstual. Yule (2002) menyatakan bahawa deiksis adalah istilah teknikal (dari bahasa Yunani) untuk salah satu perkara paling asas yang kita lakukan dengan ujaran. Ia bermaksud "menunjuk" melalui bahasa. Segala bentuk linguistik yang digunakan untuk mencapai 'penunjuk' ini disebut ekspresi diektik. Ekspresi deiktik adalah ekspresi yang peka kepada pusat deiktik yang biasanya merupakan lokasi penutur. Item leksikal yang digunakan secara deiktik termasuklah kata ganti nama diri, demostratif dan kata kerja datang dan pergi (Huang, 2015). Ekspresi diektik juga kadang-kadang disebut sebagai indeksikal. Secara tradisinya, terdapat tiga kategori asas deiksis yang sering dibincangkan dalam ilmu linguistik dan kosa ilmu falsafah bahasa iaitu dieksis orang, ruang (tempat) dan masa.

Hal ini kerana semua ekspresi 'tunjuk' mempunyai kaitan dengan ujaran seseorang, tempat ujaran dan masa ujaran. Sehubungan dengan itu, terdapat tiga jenis deiksis utama iaitu deiksis perorangan (interpretasi ujaran yang berkaitan dengan peserta dalam tindakan komunikatif, deiksis ruang/tempat (interpretasi ujaran yang berkaitan dengan tempat dalam tindakan komunikatif) dan deiksis masa (interpretasi ujaran berkaitan dengan masa dalam tindakan komunikatif). Sejajar dengan definisi ini, ungkapan deiktik, misalnya adalah kata keterangan tempat dan masa seperti di sini, di sana, hari ini, esok; kata ganti nama diri, posesif dan demonstratif; imbuhan kata kerja seseorang dan masa, dan lain-lain. Selanjutnya kategori deiksis ditambah kepada deiksis sosial dan deiksis wacana yang menurut Huang (2015), kedua-dua deiksis ini sebagai deiksis tambahan.

Deiksis ruang (spatial deixis) difahami sebagai elemen yang menetapkan "lokasi ruang yang relatif dengan peristiwa tutur" (Anderson, \& Keenan 1985: 277 dalam Dombrowsky-Hahn, Klaudia, 2012). Ia dinyatakan dalam pelbagai bahagian pertuturan: adverba lokatif, kata ganti 
nama diri, morfem mengenal pasti deiktik ("presentative”), kata kerja, imbuhan kata kerja dan lain-lain. Dalam kebanyakan bahasa, kata kerja deiktik datang dan pergi memainkan peranan yang dominan dalam sistem deiktik ruang. Secara relatifnya, kata kerja deiktik adalah kategori kecil dalam deiksis. Sehingga kini kajian terhadap kata kerja deiktik berfokus kepada kata kerja gerak seperti come dan go dan juga kata kerja kausatif bring dan take (Wang, 2018). Kata kerja deiktik juga dikenali sebagai kata kerja gerak deiktik. Kata kerja gerak deiktik merujuk kepada manamana kata kerja yang menandakan arah bagi sesuatu entiti sedang bergerak seperti come (datang) dan go (pergi) (Wang, 2018). Menurut Ricca (1993: 15), kata kerja deiktik sering disalahgunakan. Pada prinsipnya, dalam beberapa bahasa semua kata kerja adalah diektik, dengan maksud bahawa kelenturan personal dan temporal mereka berkaitan dengan deiksis orang dan masa. Walau bagaimanapun, label ini biasanya digunakan dalam bidang linguistik kepada golongan kata kerja yang sangat kecil, khususnya, kata kerja yang tafsirannya bergantung pada lokasi yang relatif kepada peserta bagi sesuatu tindakan komunikatif.

Menurut Fillmore (1997 dalam Lewandowski, 2014), kata kerja deiktik adalah kata kerja yang pentafsirannya bergantung kepada lokasi ruang dan temporal bagi lakuan tutur peserta. Sebagai contoh, dalam (1) kata kerja bahasa Sepanyol venir 'come', traer 'bring' dan ir 'go', llevar 'take' adalah deiktik, kerana dalam dua kata kerja yang pertama membayangkan kehadiran penutur pada matlamat pergerakan (iaitu disampaikan oleh kata adverba ruang aqui 'here'), sementara dua yang terakhir membayangkan ketiadaan penutur pada sasaran pergerakan (yang disampaikan oleh adverba ruang alli 'there').

(1) a. Ven / tráe-lo aquí / *allí.

come.IMP / bring.IMP-it here / there

'Come/bring it here/*there.

b. Ve / lléva-lo allí / *aquí. go.IMP / take.IMP-it here /

'Go/take it there/*here.'

Implikasi seperti itu tidak terlibat dalam makna kata kerja lain, seperti enter 'masuk', kerana interpretasinya tidak bergantung pada lokasi lakuan tutur penutur sebagaimana ditunjukkan dalam (2).

(2) Entr-a aquí / allí.

enter-IMP here / there

'Enter here/there.'

Interpretasi ungkapan deiktik mengarah kepada titik rujukan yang relevan. Dalam kes yang tidak ditandakan, pusat deiktik prototaip adalah paksi ruang-temporal dalam konteks langsung, iaitu lokasi penutur pada masa ujaran. Kata kerja gerak datang dan pergi adalah deiktik dalam maksud kata kerja ini menandakan arah sesuatu entiti itu bergerak dan pergerakan tersebut didasarkan kepada titik rujukan ruang-temporal iaitu pusat diektik. Dalam kebanyakan bahasa, kata kerja gerak datang dan pergi menunjukkan kontras deiktik iaitu dicirikan sebagai gerakan ke arah penutur vs gerakan jauh dari penutur (Miller, \& Johnson-Laird, 1976; Talmy, 2000). Fillmore (1971) juga memberikan analisis asas terhadap kata kerja deiktik gerak dalam bahasa Inggeris. Beliau berpendapat bahawa come (datang) digunakan untuk merujuk kepada pergerakan ke lokasi 
penutur atau pendengar pada saat peristiwa gerakan atau ucapan, sementara go (pergi) digunakan untuk merujuk kepada pergerakan ke suatu lokasi yang penutur tidak berada pada masa ujaran.

Kata kerja deiktik dalam bahasa-bahasa lain adalah serupa kecuali banyak bahasa yang hanya menggunakan lokasi penutur sebagai pusat deiktik. (Yo Matsumoto, Kimi Akita, \& Kiyoko Takahashi t.th.; Huang, 2015). Menurut Wang (2018), kata kerja deiktik yang terangkum di bawah kategori deiksis ruang (space deixis) secara relatifnya masih menjadi bidang penyelidikan yang agak kecil berbanding dengan jenis-jenis deiksis yang lain. Oleh itu kategori deiksis ini harus dikaji dan diterokai. Justeru makalah ini bertujuan menganalisis semantik leksikal bagi kata kerja deiktik dengan memberi fokus kepada kata kerja datang dan pergi dalam bahasa Melayu. Selanjutnya makalah ini juga akan menjelaskan cara penutur membina spesifikasi lokasi dalam ruang yang relatif kepada peserta pada masa koding (Coding Time-CT) dalam sesuatu peristiwa pertuturan.

\section{Kata kerja deiktik bahasa Melayu}

Dalam bahasa Melayu deiksis boleh dikodkan terutamanya dalam bentuk kata kerja deiktik atau frasa kata kerja atau melalui frasa preposisi, sebagaimana dijelaskan dalam ayat (3) dan (4) berikut:

(3) Adik pergi ke sekolah. (kata kerja)

(4) Adik berjalan ke padang (frasa preposisi)

Dalam ayat (3), deiksis dinyatakan dalam bentuk kata kerja deiktik. Manakala dalam ayat (4), ekspresi deiksis menggunakan frasa preposisi (ke padang) yang bertindak sebagai deiktik arah bagi menandakan arah sasaran lokasi. Kata kerja deiktik juga dikenali sebagai kata kerja gerak deiktik. Kata kerja gerak boleh didefinisikan sebagai kata kerja yang melibatkan lakuan gerak dan gerakan itu boleh mengakibatkan perubahan lokasi atau tidak. Hal yang sama ditunjukkan dalam bahasa Inggeris dan bahasa Sepanyol yang mana kata kerja gerak -ir, venir, llevar dan traer (to come, to take dan to bring) dianggap sebagai mempunyai komponen arah yang membolehkan kata kerja ini digunakan dalam hubungannya dengan lokasi peserta dalam perbualan yang lazimnya merujuk kepada posisi penutur dan menambah maklumat kontekstual kepada wacana. Oleh sebab ciri khusus ini menjadikan kata kerja ini berbeza daripada kata kerja gerak yang lain dan dikenali sebagai kata kerja gerak deiktik (Colasacco, Marina Anna, 2019). Kata kerja gerak boleh dibahagikan kepada empat jenis iaitu:

i. Kata kerja gerak yang secara inheren bersifat berarah seperti datang, pergi, masuk, kembali, muncul dan sebagainya.

ii. Kata kerja meninggalkan seperti meninggalkan.

iii. Kata kerja cara gerak seperti berlari, berjalan, berpusing dan sebagainya.

iv. Kata kerja gerak menggunakan kenderaan seperti berbasikal, berkayak, berkereta dan sebagainya.

Dalam bahasa Inggeris, kata kerja gerak deiktik ialah come dan go, dalam bahasa Jerman, kommen dan gehen. Manakala dalam bahasa Sepanyol, kata kerja gerak deiktik ialah ir dan venir. Dalam bahasa Melayu, kata kerja gerak deiktik ialah datang dan pergi. Kata kerja datang dan pergi adalah kata kerja gerak yang secara inheren bersifat berarah (ke lokasi). Mengikut Kamus 
Dewan Edisi keempat (2010), maksud pergi ialah berjalan ke tempat lain; meninggalkan tempat yang mula-mula. Contohnya Dia pergi ke pasar. Manakala maksud kata kerja datang bertentangan dengan maksud kata kerja pergi iaitu datang bermaksud sampai (tiba) di sesuatu tempat, contohnya dalam ayat Dia datang ke rumah saya pada pukul 4 petang; Kata kerja datang juga mempunyai maksud bergerak menghampiri (menemui) seseorang atau sesuatu tempat, misalnya dalam ayat Setibanya di situ, dia terus datang ke tempat kami. Selain membawa maksud gerak, kata datang juga membawa maksud masa (akan tiba), kemudian dan juga membawa maksud berasal. Misalnya dalam ayat berikut:

(5) Emaknya hendak pergi ke Mekah pada tahun yang akan datang.

(6) Dia datang dari Sabah.

Kata kerja datang dalam konteks ayat (5) membawa maksud masa kemudian dan dalam ayat (6), datang bermaksud berasal. Walau bagaimanapun, dalam konteks kajian ini, tumpuan hanya diberikan kepada kata kerja datang yang mempunyai maksud pergerakan ke lokasi atau tempat. Justeru perkataan datang yang membawa maksud masa dan berasal akan diabaikan dalam kajian ini.

Kata kerja cara gerak datang dan pergi boleh mengelirukan pengguna bahasa. Salah satu sebab kekeliruan yang berlaku ialah datang dan pergi mempunyai makna asas yang sama iaitu, lakuan pelaku dalam kedua-dua kata kerja ini mempunyai arah sasaran dan titik penamat/penyempurnaan bagi aktiviti/proses yang berlaku (Maslida et al. 2010). Persamaan ini menjadikan penggunaan kata kerja pergi dan datang boleh bertukar ganti oleh penutur bahasa Melayu. Misalnya dalam ayat berikut:

(7) Boleh saya datang (ke) rumah awak?

(8) Boleh saya pergi (ke) rumah awak?

Dalam ayat (7) dan (8) menunjukkan kehadiran preposisi arah ke adalah opsyenal. Hal ini kerana komponen makna arah tumpuan itu sudah tersirat dalam kata pergi dan datang (Asmah $\mathrm{Hj}$. Omar, 2009). Walaupun kata kerja datang dan pergi boleh muncul secara silih berganti sebagaimana dalam ayat (7) dan (8) namun, ada situasi yang mana kedua-dua kata kerja ini tidak boleh muncul secara silih berganti sebagaimana ditunjukkan dalam ayat (9).

(9) “Ke mana dia pergi”/*datang?

Asmah Hj Omar (2009) ada menyatakan kata kerja seperti pergi dan datang sebagai perbuatan gerak yang merujuk kepada perbuatan yang bergerak dari satu titik ke titik yang lain. Kata kerja seperti ini boleh bergabung dan berfungsi dengan adverba arah seperti sana, sini atau situ sebagaimana contoh berikut:

(10) Dia hendak pergi (ke) sana/situ/ *sini.

(11) Dia tadi datang (ke) sini/* sana. 
Adverba arah menyatakan dari mana atau ke mana bergeraknya sesuatu perbuatan atau peristiwa itu (Asmah Hj Omar, 2009:360). Daripada segi pola kemunculan adverba arah menunjukkan kata kerja datang tidak boleh muncul dengan adverba sana atau situ dan kata kerja pergi tidak muncul dengan adverba sini. Dalam konteks pergerakan, kata kerja datang dan pergi dianggap sebagai kata kerja diektik atau kata kerja gerak deiktik yang mana interpretasi kata kerja ini berkait dengan lokasi ujaran peserta. Misalnya dalam ayat (12) dan ayat (13).

(12) Saya datang ke rumah Siti.

(13) Saya pergi ke rumah Siti.

Contoh (12) menunjukkan kehadiran penutur di tempat tersebut yang merupakan sasaran bagi pergerakan (rumah Siti) pada masa ujaran, sedangkan dalam ujaran (13) menunjukkan ketidakhadiran penutur di tempat yang menjadi sasaran/matlamat pergerakan pada masa ujaran itu berlangsung. Dengan kata lain, perbezaan kedua-dua kata kerja ini pula ialah kedua-duanya digunakan untuk arah yang berbeza. Justeru kajian ini akan menjelaskan maksud kedua-dua kata kerja gerak ini dalam konteks penggunaan bahasa agar pengguna bahasa lebih memahami maksud dan penggunaan kedua-dua bentuk kata kerja tersebut.

\section{Kajian literatur}

Dalam peristiwa gerak, semua bahasa dikatakan mempunyai kelas kata kerja gerak yang bersamaan dengan kata kerja bahasa Inggeris come (datang) dan go (pergi). Kata kerja ini memaparkan pertentangan deiktik yang universal (Miller, \& Johnson-Laird, 1976; Talmy, 2000, dalam Lewandowski, 2014).

Dalam akademia barat, kebanyakan kajian memfokuskan kepada kata kerja gerak come (datang) dan go (pergi) bersama dengan kata kerja gerak yang lain seperti leave (meninggalkan), depart (berlepas), bring (membawa) dan take (mengambil) (Wang, 2018). Kajian Ricca (1993) mengenai kata kerja come dan go dalam bahasa-bahasa Eropah yang berdasarkan pendekatan Fillmore membezakan antara bahasa yang deiktik sepenuhnya (fully deictic languages), bahasa yang sebahagian besarnya diektik (predominantly deictic languages) dan bahasa yang bukan deiktik (non-deictic Languages). Dalam kumpulan pertama kata kerja come dan go menunjukkan perilaku deiktik yang ketat. Bahasa-bahasa yang deiktik sepenuhnya ialah bahasa Itali, Sepanyol, Portugis, Hungary, Yunani, Albania atau Finland. Dalam bahasa-bahasa ini kata kerja come dan go mengambil interpretasi deiktik dalam sebilangan besar penggunaannya. Yang kedua, bahasabahasa yang mana dimensi deiktik menjadi penentu dalam penggunaan kata kerja deiktik come dan go di samping terdapat juga faktor-faktor lain yang turut memainkan peranan. Ricca mengklasifikasikan bahasa-bahasa yang deiktiknya predominan adalah seperti bahasa Jerman, Swedish, Danish, Dutch, Slovenian, Serbia, Croatia, French dan English. Ciri distingtif bahasabahasa ini adalah penyebaran yang luas bagi kata kerja come. Pertama, kata kerja ini digunakan dalam konteks pergerakan menuju ke arah penutur dan pendengar (kedua-duanya dalam pengekodan dan juga pada masa rujukan) dan kedua, dalam beberapa bahasa ini kata kerja come juga memperlihatkan tingkah laku bukan deiktik yang dikaitkan dengan faktor aspektual iaitu faktor yang berkaitan dengan titik penamat Aktionsart (merupakan perkataan Jerman yang bermaksud 'bentuk lakuan'). Aktionsart berhubungan dengan struktur temporal dalaman bagi 
sesuatu peristiwa). Kumpulan ketiga pula terdiri daripada bahasa yang kata kerja come dan go tidak melibatkan deiksis dalam interpretasi ujaran yang mengandungi kata kerja ini. Dalam kumpulan ini, termasuklah bahasa-bahasa seperti bahasa Rusia, Ukrainian, Lithuanian, Polish dan Czech. Dalam bahasa-bahasa ini kata kerja come dan go lazimnya tidak mengungkapkan pertentangan deiktik. Kata kerja gerak yang sama boleh digunakan dalam konteks pergerakan ke arah orang pertama, orang kedua dan orang ketiga.

Nakazawa (2007), telah meneliti kata kerja gerak deiktik come dan go dalam pelbagai bahasa iaitu bahasa Cina, Bahasa Inggeris, Jerman, Jepun, Korea, dan Shibe, serta bahasa-bahasa lain dalam literatur dengan menggunakan Kerangka Talmy untuk menganalisis kata kerja gerak. Analisis kata kerja gerak deiktik dalam pelbagai bahasa menunjukkan bahawa terdapat crossclassified hierarchy antara elemen-elemen yang membentuk tanda tempat (ground) iaitu semua bahasa mengambil lokasi penutur pada masa ujaran sebagai pusat deiktik. Sementara itu, dalam beberapa bahasa juga, lokasi penerima dan/atau lokasi rujukan masa memainkan peranan sebagai pusat deiktik. Kajian ini juga menunjukkan bahawa dalam beberapa bahasa, tanda tempat bagi kata kerja gerak deiktik dihubungkan semula dengan referen elemen ayat tertentu seperti subjek bagi subjek matriks, dan bukannya dipautkan kepada peserta bagi lakuan tutur, yang biasanya dianggap menentukan pusat deiktik.

Dalam bahasa Melayu, belum ada lagi kajian yang meneliti secara tuntas maksud kata kerja deiktik dalam konteks ujaran. Kata kerja deiktik yang terangkum di bawah deiksis ruang adalah ujaran yang memerlukan maklumat kontekstual. Sehingga kini, kajian-kajian barat terhadap kata kerja deiktik memberi fokus kepada kata kerja gerak seperti datang dan pergi. Dapatan utama kajian-kajian ini mengaitkan kata kerja datang dan pergi dengan pusat deiktik. Dengan demikian, sebagai perbandingan dengan bahasa-bahasa lain yang telah dikaji mengenai kata kerja deiktik, kajian ini berusaha untuk memberi gambaran interpretasi ekspresi deiktik dalam konteks korpus bahasa Melayu. Dapatan kajian ini berupaya menambah kosa ilmu dan rujukan yang berkaitan dengan kata kerja gerak deiktik sebagai antara bahasa yang telah dikaji.

\section{Metodologi}

Kajian ini menggunakan pendekatan deskriptif iaitu menghurai dan menjelaskan fenomena bahasa. Untuk mendapatkan contoh kata kerja datang dan pergi dalam ayat, kajian ini menggunakan Pangkalan Data Korpus Dewan Bahasa dan Pustaka (DBP) dengan memilih bahan akhbar, majalah dan teks sastera sebagai sumber carian korpus. Rusli (2008), menjelaskan korpus yang bersinonim dengan korpus komputer adalah sebagai himpunan teks digital yang dikumpulkan berdasarkan kriteria tertentu dan digunakan untuk meneliti pelbagai aspek kebahasaan. Penyelidikan berasaskan analisis data korpus disifatkan sebagai salah satu komponen dalam deskriptif kualitatif iaitu 'penyelidikan yang menghasilkan dapatan yang bukan melalui prosedur statistik atau lainlain bentuk pengiraan' (Strauss, \& Corbain, 1990). Hal ini relevan, kerana kebanyakan kajian korpus boleh memanfaatkan perkataan dan ayat untuk dikaji secara deskriptif. Kaedah ini didapati bersesuaian dengan matlamat sesuatu kajian untuk meneroka, membuat interpretasi dan mendapat pemahaman yang mendalam tentang sesuatu fenomena kebahasaan, dan bukannya menguji suatu hipotesis.

Carian bagi kata kerja datang dan pergi dihadkan kepada lingkungan konteks lapan kata ke kiri dan ke kanan. Lingkungan konteks lapan kata ke kiri dan ke kanan memadai untuk 
menunjukkan konteks kata kerja yang diteliti. Kajian ini menetapkan 100 bilangan konkordans sahaja bagi setiap kata kerja

Konkordans ialah satu perisian/program yang membolehkan penyenaraian kekerapan sesuatu perkataan dalam sesebuah teks dalam baris yang sama. Konkordans memperlihatkan konteks perkataan yang berada sebelum dan selepas perkataan pilihan. Menurut Abdullah Yusof (2006), konkordans sebagai baris-baris petikan yang tersenarai dalam data korpus. Konkordans ini tersenarai mengikut perkataan yang dikehendaki oleh pengguna sendiri. Perkataan yang dikehendaki atau yang dikaji berada di tengah-tengah baris konkordans dan dinamakan sebagai kata kunci Key Word in Context (KWIC). Sebagai contoh diberikan senarai konkordans bagi carian kata kerja pergi dalam Pangkalan data Korpus DBP.

\section{KEPUTUSAN CARIAN CONCORDANCE}

Carian kata: pergi

Bil. Konkordans: 100 konkordans dijumpai.

(14) Petugas itu menjawab: "Dia pergi minum, 15 minit..."

(15) “...ini dan juga dari luar sanggup pergi ke Teluk Tempoyak yang terletak...”

(16) "Ketika menjadi perenang dulu saya pergi ke kolam renang dan pulang ke..."

Berdasarkan bentuk tipikal yang ditunjukkan oleh baris-baris konkordans, maka seseorang pengkaji boleh melakarkan pola bahasa yang diteliti. Tambahan pula, peranti analisis data korpus bukan sekadar menunjukkan kolokasi perkataan, tetapi juga frekuensi kata dan frasa (Norliza, 2015).

\section{Pendekatan semantik kata kerja gerak deiktik}

Dalam menganlisis kata kerja gerak deiktik datang dan pergi, kajian ini akan menggunakan model Talmy $(1975,1985,2000)$ yang berasaskan kepada konsep pusat deiktik. Pusat deiktik adalah konsep utama dalam penelitian deiksis. Pusat deiktik merupakan titik rujukan yang ekspresi deiktik bergantung kepadanya. Dalam kes yang tidak tertanda (unmarked case), pusat deiktik yang prototaip ialah paksi ruang-temporal dalam konteks ujaran iaitu lokasi penutur pada masa ujaran (Wang, 2018). Dalam kerangka Talmy, beberapa kata kerja gerak adalah deiktik iaitu kata kerja ini menandakan arah bagi sesuatu entiti yang bergerak dan pergerakan ini didasarkan kepada titik rujukan ruang-temporal, iaitu pusat deiktik. Oleh itu, pusat deiktik bagi mana-mana kata kerja gerak akan difahami sebagai penyilangan bagi bahagian yang kompleks bagi skema SUMBERLALUAN-MATLAMAT, dan pusat deiktik yang tidak bertanda adalah penutur dan lokasi penutur pada masa ujaran. Sebagai contoh, secara inherennya kata kerja seperti come, arrive, reach dan bring memprofil matlamat/sasaran bagi pergerakan ke arah penutur. Sementara itu, kata kerja seperti go, leave, depart dan take secara inherennya memprofil sumber bagi pergerakan jauh daripada penutur dan secara inherennya pula kata kerja seperti move, pass dan travel memprofil laluan bagi pergerakan yang tidak relevan dengan lokasi penutur. Talmy $(1975,1985,2000$ dalam Nakazawa, 2007) memformalisasikan situasi yang mengandungi gerak sebagai peristiwa Gerak (Motion Event). Peristiwa Gerak asas dianalisis sebagai mengandungi objek (the figure) dan 
pergerakannya melalui Laluan (the Path) yang berhubungan dengan Objek rujukan yang lain (the Ground). Komponen-komponen ini boleh dikenal pasti sebagaimana dalam contoh ayat berikut:

(17) The bottle moved into the cove.

[Figure] [Motion] [Path] [Ground]

[objek] [ Gerak] [Laluan] [tanda tempat]

Sesetengah kata kerja gerak seperti enter dan exit, mengungkapkan bukan sahaja fakta tentang Gerak sebagaimana dalam (17) tetapi juga (sebahagiannya) menyatakan maklumat Laluan seperti 'into/out of an enclosure'. Kata kerja gerak yang memasukkan Laluan bagi gerak dalam makna leksikal kata kerja tersebut dipanggil sebagai Kata kerja gerak gabungan-Laluan (Path-conflating motion verbs). Menurut Talmy, kata kerja gerak deiktik adalah sejenis kata kerja gabungan-Laluan (Path-conflating) dengan pilihan khusus bagi Laluan dan Tanda tempat. Komponen deiktik bagi Laluan lazimnya hanya mempunyai dua konsep keahlian iaitu 'menuju ke arah pusat diektik (penutur)' dan 'dalam arah selain ke arah pusat deiktik (penutur)' (Talmy, 2000). Dengan demikian, makna leksikal datang boleh dianggap sebagai "BERGERAK KE ARAH" (MOVE TOWARD) titik yang merupakan lokasi penutur. Sementara itu makna leksikal bagi pergi adalah "BERGERAK KE ARAH" titik yang bukan merupakan lokasi penutur.

Oleh itu, makna leksikal bagi kata kerja come (datang) adalah penggabungan (conflated) dengan penutur sebagai tanda tempat sebagaimana ditunjukkan dalam (18).

\section{(18) COME}

MOVE TOWARD a point which is the location of the speaker

[Motion] [Vector ] [Conformation ] [Ground ] [Path ]

[Gerakan] [Laluan] [Penyesuaian] [Tanda Tempat]

(Nakazawa, 2006)

MOVE (GERAK) ialah kata kerja abstrak yang menggambar gerakan dalam peristiwa gerak dan TOWARD (KE ARAH) ialah komponen Laluan yang dipanggil Vektor. Vektor menyatakan "jenis-jenis asas bagi ketibaan, melintas dan perlepasan yang dapat dilaksanakan oleh skema Figural berkenaan dengan skema tanda tempat" (Talmy, 2000:53). Secara umumnya, pusat deiktik yang tak tertanda ialah penutur, namun sebagaimana yang disedari oleh Talmy, pusat deiktik boleh beralih kepada individu selain daripada penutur iaitu individu yang menjadi perspektif penutur. Walau bagaimanapun, peralihan deiktik ini bukanlah mudah kerana peralihan ini bergantung kepada pelbagai keterbatasan seperti topikaliti dan juga kadang kala bergantung kepada sifat khusus bahasa. Kerangka analisis Talmy (Talmy, 1975, 1985, 2000) membolehkan satu skema makna kata kerja gerak deiktik dilihat daripada perspektif gabungan kata kerja- laluan dalam bahasa Melayu.

\section{Analisis dan Perbincangan}

Kata kerja gerak diektik datang dan pergi adalah kata kerja gerak yang memasukkan spesifikasi makna arah gerak walaupun tanpa kehadiran kata komplemen arah (Levin 1993). Komponen makna bagi kata kerja datang dan pergi secara semula jadi difahami sebagai memasukkan 
komponen lokasi bagi arah gerakan walaupun tanpa kehadiran preposisi lokatif arah dalam ayat. Dengan demikian, daripada janaan data kata kerja deiktik datang dan pergi dalam korpus DBP juga mendapati ada ayat yang mengandungi kata kerja ini muncul dengan preposisi arah ke dan ada variasi ayat yang tidak hadir dengan preposisi arah ke sebagaimana paparan data berikut:

(19) “...dia berasa malu dengan orang-orang kampung yang sering kali datang bertandang di rumah itu".

(20) “Ayuh, naik tidur Iral!” kata ayahnya yang tiba-tiba datang ke kandang itu.

(21) "Kemudian, Cikgu Sahadi datang semula dengan kuih dan nasi”.

(22) "Biar aku yang pergi dahulu".

(23) "Tetapi Kiyoaki menggesanya supaya pergi ke Gesshu dan membuat permohonan terakhir kepada Ketua..."

(24) "Pagi itu dia pergi ke sungai menjala ikan seperti biasanya".

Dalam bahasa Melayu, pemahaman maksud kata kerja gerak datang dan pergi juga berasaskan kepada pusat diektik. Menurut Talmy, kata kerja gerak deiktik merupakan kata kerja gabungan-Laluan yang menandai secara khusus Laluan dan Tanda Tempat. Lazimnya komponen deiktik laluan menjurus kepada 'ke arah penutur' dan 'dalam arah yang selain daripada arah ke penutur'. (Talmy, 2000). Dengan demikian, kata kerja gerak deiktik datang dan pergi menunjukkan pengekodan gerakan ke arah atau menjauhi pusat deiktik. Talmy $(1975,2000)$ menunjukkan bahawa GO menerangkan gerak dari pusat deiktik sementara COME menerangkan gerak ke (arah) pusat deiktik. Penjelasan yang sama pada bahasa Melayu yang mana ayat (7) dan (8) yang diulang sebagai (25) dan (26) iaitu kata kerja datang menerangkan gerakan ke arah pusat deiktik (rumah), manakala pergi menerangkan gerakan dari pusat deiktik.

(25) Boleh saya datang (ke) rumah awak?

(26) Boleh saya pergi (ke) rumah awak?

Berdasarkan data daripada korpus bahasa Melayu, kata kerja pergi menunjukkan makna "BERGERAK KE ARAH" titik yang bukan merupakan lokasi penutur/peserta. Syarat bagi penggunaan kata kerja pergi secara umumnya dapat dinyatakan sebagai gerakan menjauhi lokasi penutur/peserta pada masa pertuturan. Komponen makna bagi kata kerja pergi memasukkan komponen lokasi bagi arah gerakan dengan atau tanpa kehadiran preposisi lokatif pada ayat iaitu preposisi ke. Ayat (27) - (30) menunjukkan contoh kemunculan kata kerja gerak pergi dalam korpus bahasa Melayu.

(27) Maka Mak Inang pun pergi ke Bukit Siguntang.

(28) Selepas itu, Mat Yusof pergi ke kereta itu dan mengetuk cermin tingkap. 
(29) Yuhainis pergi ke rumah Asrif.

(30) Haji Bakhil telah pun bersiap berpakaian hendak pergi pejabat.

Dalam ayat (27) - (30), didapati kata kerja pergi menandakan peserta/pelaku bergerak dari pusat deiktik dan semakin menjauhi pusat diektik iaitu lokasi penutur/peserta pada masa koding. Peserta iaitu Mak Inang (ayat 27), Mat Yusof (ayat 28), Yuhainis (ayat 29) dan Haji Bakhil (ayat 30) melakukan pergerakan daripada sumber lokasi, dan melalui sesuatu lokasi dan sasaran/tanda tempat pada sesuatu lokasi baharu iaitu Bukit Siguntang, kereta, rumah Asrif dan pejabat. Gerakan menjauhi pusat deiktik ini menjelaskan mengapa kata kerja gerak deiktik pergi tidak boleh menerima adverba arah 'ke/di sini' sebagaimana ditunjukkan dalam ayat (31). Hal ini adalah disebabkan 'ke/di sini' membawa maksud dekat dengan pusat diektik iaitu penutur manakala adverba arah ke/di sana membawa maksud yang sejajar dengan makna pergi iaitu jauh dari pusat diektik.

(31) Adik pergi ke sana/* ke sini/* di sini.

Nakazawa (2006) mendakwa makna leksikal come (datang) adalah 'GERAK KE (ARAH)' titik yang merupakan lokasi penutur. Makna leksikal datang boleh dilihat sebagai penggabungan dengan penutur sebagai tanda tempat (the Ground). Tanda tempat ialah rujukan objek yang berhubungan dengan pergerakan objek dan mengikut Talmy, tanda tempat bagi kata kerja gerak deiktik lazimnya adalah penutur (Nakazawa, 2007). Berikut ialah contoh-contoh ayat yang mengandungi kata kerja datang dalam korpus.

(32) "Ipah pula akhir-akhir perpindahannya memang jarang datang ke rumah saya, katanya sibuk dengan tugas baru..."

(33) “Ayuh, naik tidur Iral!” kata ayahnya yang tiba-tiba datang ke kandang itu.

(34) “Tunggu, tunggu ibu datang," sahut Piah dari dalam bilik.

(35) "Selalu tak orang datang ke mari, bang?” tanya Rahmat.

Dalam ayat (32)- (35), makna kata kerja datang jelas menunjukkan penggabungannya dengan peserta/penutur pada satu tanda tempat iaitu kampus, kandang dan lokasi tertentu. Dalam makna kata kerja datang, pergerakan peserta adalah ke arah pusat diektik iaitu tanda tempat. Dengan kata lain, kata kerja gerak datang memberi fokus kepada sasaran atau matlamat bagi pergerakan dan tidak seperti kata kerja gerak pergi yang menekankan sumber pergerakan iaitu titik mula sesuatu pergerakan. Penyataan ini menyamai Fillmore (1971) yang dipetik daripada Lewandowski, W, 2007 yang juga membuat pemerhatian yang berkaitan dengan apa yang disebutnya sebagai "tempat rujukan" (reference place): go memfokuskan pada Sumber gerakan (iaitu titik keberangkatan), sedangkan come memberi tumpuan kepada Matlamat gerakan (iaitu tempat titik ketibaan). Perbezaan kedua-dua kata kerja gerak ini dapat diskema seperti berikut: 


\section{Pergi}

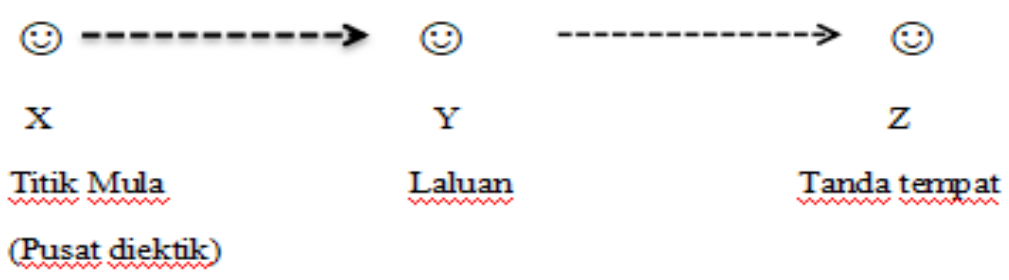

\section{Datang}

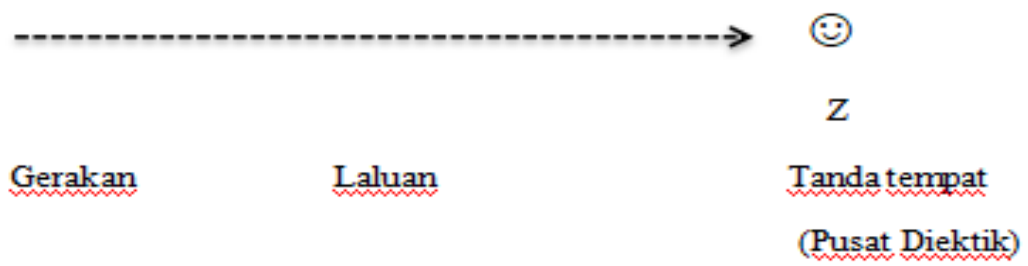

Pertentangan kedua-dua kata kerja ini dapat diperjelaskan dalam ayat (36) dan ayat (37) berikut:

(36) Saya datang ke sekolah pada pukul 7 pagi.

(37) Saya pergi ke sekolah pada pukul 7 pagi.

Dalam (36), spesifikasi temporal adalah pada pukul 7 pagi yang menandakan masa ketibaan penutur. Manakala dalam (37), ia menandakan masa perlepasan penutur pada pukul 7 pagi. Dengan perkataan lain, kata kerja pergi mengandungi ciri Aktionsart inchoactive iaitu permulaan kepada keadaan yang baru (lokasi baru) manakala kata kerja datang mengandungi ciri Aktionsart penamat (memberi fokus kepada penamat).

Konsep bagi Tanda Tempat dalam semantik kata kerja datang sejajar dengan "pusat deiktik" tempat/ruang (Fillmore, 1975), dan tidak dinafikan bahawa kebanyakan pusat asas deiksis adalah pada lokasi penutur pada masa lakuan tutur. Misalnya dalam data bahasa Melayu (32) dan (35), pergerakan pelaku adalah pada arah penutur sebagai pusat deiktik (ke rumah saya dan ke mari). Pergerakan peserta ke pusat deiktik dapat menjelaskan kehadiran kata adverba arah ke mari dan ke sini bersama dengan kata datang dalam ayat. Perkataan ke mari dan ke sini menunjukkan lokasi penutur jauh daripada pendengar. Walau bagaimanapun ramai sarjana (seperti Fillmore, 1966; Lyons, 1977; Levinson, 1983 dalam Wang, 2014) berpandangan bahawa lokasi pendengar juga memainkan peranan sebagai Tanda tempat dan gerakan menuju ke arah pendengar juga boleh diterangkan sebagai datang dalam bahasa. Hal yang sama juga diterangkan oleh Talmy yang menyatakan bahawa pusat deiktik boleh beralih kepada individu selain daripada penutur iaitu berdasarkan perspektif penutur. Hal yang sama dapat ditunjukkan dalam ayat (33) dan (34) yang mana kata kerja gerak datang merujuk pergerakan menuju ke arah lokasi Ira dalam (33) dan lokasi pendengar dalam (34). Berdasarkan analisis, kajian ini juga mendapati kata kerja gerak datang 
dan pergi mempunyai hubungan dengan adverba ruang arah ke sini, ke mari dan ke sana yang mana dalam bahasa Melayu, didapati penggunaan bentuk kata kerja gerak deiktik yang muncul bersama kata adverba arah seperti dalam ayat (38) dan (39) berikut:

(38) ...datang ke sini/sini/ ke mari

*...pergi ke sini/sini/ke mari

(39) ...pergi ke sana/sana

* ...datang ke sana/sana

Kata kerja gerak datang membayangkan kehadiran penutur atau pendengar pada matlamat pergerakan yang berhubungan dengan kehadiran adverba arah ruang di/ke sini dan ke mari, sementara kata kerja gerak pergi membayangkan ketiadaan penutur pada sasaran pergerakan yang lazimnya kata kerja ini boleh mengambil adverba arah ke sana iaitu gerak menuju ke arah penutur atau pendengar. Hal ini demikian kerana kata kerja datang menerangkan gerakan ke arah penutur atau ke arah proksinya (individu yang perspektifnya diambil oleh penutur), maka maksud kata kerja datang sejajar dengan maksud adverba arah sini dan mari yang menerangkan lokasi dekat dengan penutur. Manakala kata kerja pergi membawa maksud gerakan daripada penutur atau daripada proksinya (individu yang perspektifnya diambil oleh penutur). Oleh sebab, kata kerja pergi menunjukkan maksud perlepasan daripada titik gerak maka ia berhubungan dengan adverba arah ke sana/sana yang merujuk kepada posisi jauh daripada penutur atau pendengar.

\section{Kesimpulan}

Kajian ini telah menunjukkan bahawa bahasa Melayu seperti bahasa-bahasa lain yang telah kaji (antaranya bahasa Inggeris, Sepanyol dan bahasa Jepun) mempunyai kelas kata kerja gerak yang mempamerkan pertentangan deiktik pergerakan ke arah penutur lwn pergerakan jauh daripada penutur. Dalam bahasa Melayu pertentangan deiktik ini ditunjukkan oleh kata kerja gerak datang dan pergi. Daripada data korpus bahasa Melayu, didapati interpretasi pergerakan kata kerja datang dan pergi berhubungan dengan pusat deiktik iaitu titik rujukan yang berkaitan dengan ekspresi deiktik yang akan diinterpretasikan dan kebiasaannya merujuk kepada penutur. Dengan demikian pergi menerangkan gerak dari pusat deiktik dan menjauhi pusat deiktik, manakala datang menerangkan gerak ke arah pusat deiktik. Selain itu, analisis data korpus juga dapat menjelaskan bahawa kata kerja gerak datang berdasarkan orientasi perspektif- ketibaan sedangkan kata kerja gerak pergi berdasarkan orientasi perspektif- perlepasan. Kajian tentang kata kerja deiktik datang dan pergi harus diperluaskan lagi agar pemahaman dan kejelasan yang lebih berpada dan menyeluruh khususnya dalam memahami komponen deiktik kata kerja gerak yang lain seperti sampai, masuk, keluar, bawa, ambil dan juga kata arah deiktik seperti di sini, ke sana, ke mari dan lain-lain lagi.

\section{Penghargaan}

Kajian ini merupakan sebahagian daripada hasil penyelidikan UKM-SK-05-FRGS0074-2009 (Pengelasan baru kata kerja: satu analisis morfosemantik). 


\section{Rujukan}

Antonopoulou, E, \& Nikiforidou, K. (2002). Deictic motion and the adoption of perspective in Greek. Pragmatics, 12(3), 273-29. DOI: 10.1075/prag.12.3.02ant.

Asmah Hj. Omar. (2009). Nahu Melayu mutakhir. Kuala Lumpur, Dewan Bahasa dan Pustaka.

Colasacco, Marina Anna. (2019). A cognitive approach to teaching deictic motion verbs to German and Italian students of Spanish. IRAL, 57(1), 71-95. https://doi.org/10.1515/iral.2018-2007.

Dombrowsky-Hahn, Klaudia. (2012). Grammaticalization of the deictic verbs 'come' and 'go' in Syer (Senufo, Gur). https://www.academia.edu/33896840/Grammaticalization_of_the_ deictic_verbs_come_and_go_in_Syer_Senufo_Gur_2012_

Fillmore, J.C. (1966). Deictic categories in the semantics of come. Foundations of Language, 2, 219-227.

Fillmore, J.C. (1971). Toward a theory of deixis. In. University of Hawaii Working Papers in linguistics, 3, 219-242.

Huang,Y. (2015). Pragmatics. Second edition. New York, Oxford University Press.

Kamus dewan edisi keempat. (2010). Kuala Lumpur, Dewan Bahasa dan Pustaka.

Lewandowski, W. (2007). Toward a comparative analysis of coming and going verbs in Spanish, German, and Polish. Master Thesis. https://core.ac.uk/download/pdf/13283487.pdf.

Lewandowski, W. (2014). Deictic verbs: Typology, thinking for speaking and SLA. SKY Journal of Linguistics, 27, 43-65.

Levin, B. (1993). English verb classes and alternations: A preliminary investigation. Chicago, The University of Chicago Press.

Maslida Yusof, Nor Hashimah Jalaluddin, Zaharani Ahmad, \& Karim Harun. (2010). Analisis situasi kata kerja gerak bahasa Melayu. Jurnal Linguistik, 11, 1-17.

Nakazawa, Tsuneko. (2006). Motion event and deictic motion verbs as path conflating verbs. In S. Müller, ed., The Proceedings of the 13th International Conference on Head-Driven Phrase Structure Grammar (pp. 284-304). Stanford, CSLI Publications.

Nakazawaa, T. (2007). Typology of the ground of deictic motion verbs as path-conflating verbs: The speaker, the addressee, and beyond Tsuneko. Poznań Studies in Contemporary Linguistics, 43(2), 59-82.

Norliza Jamaluddin. (2015). Penelitian tatabahasa: Antara data korpus dengan intuisi. http://mabbim.dbp.my/wordpress/wp-content/uploads/2015/04/05-Norliza-Jamaluddin_Malaysia_.pdf

Oshima, D.Y. (2006). GO and COME Revisited: What Serves as a Reference Point? Proceedings of the 32nd Berkeley Linguistics Society. DOI: http://dx. doi.org/10.3765/bls.v32i1.3466.

Rusli Abdul Ghani, Norhafizah Mohamed Husin, \& Chin Lee Yim. (2008). Pangkalan data korpus DBP: Perancangan, pembinaan dan pemanfaatan. Dalam Zaharani Ahmad (Pnyt.), Aspek nahu praktis bahasa Melayu (hlm. 21-36). Bangi, Penerbit Universiti Kebangsaan Malaysia.

Talmy, L. (1975). Semantics and syntax of motion. In Kimball, J.P. (Ed.), Syntax and Semantics 4 (pp. 181-238). New York, Academic Press.

Talmy, L. (2000): Typology and process in concept structuring. toward a cognitive semantics, vol. 2. Cambridge, London, The MIT Press.

Talmy, L. (2020). Targeting in Language: Unifying Deixis and Anaphora. https://www.frontiersin.org/articles/10.3389/fpsyg.2020.02016/full 
Wang Chunrong. (2018). Deictic verbs in modern linguistics. Advances in Social Science, Education and Humanities Research, 283, 481-487.

Yo Matsumoto, Kimi Akita, and Kiyoko Takahashi. (t.th.). The interactional nature of deictic verbs in English, Japanese, and Thai: Why Deixis must be treated separately from Path. http://www.lit.kobe-u.ac.jp/ yomatsum/papers/ DeixisEngJapTha.pdf 